\title{
A COMPARISON BETWEEN EU AND BRAZILIAN WATER POLICIES: THE USE OF MACROINVERTEBRATES
}

\author{
Abel Silva Vieira \\ Guilherme Araujo Gomes \\ Renê Lebarbenchon Macêdo \\ Federal University of Santa Catarina, Brazil
}

\begin{abstract}
Water management has traditionally looked at the physical-chemical measurements which are not enough to protect the ecosystems in a more detailed watershed management. The European Union (EU) and Brazil have been attempting to improve their water status by the implementation of the Water Frame Directive (WFD) and the Brazil's National Water Resources Plan (PNRH) respectively. Despite of many similarities between the policies, they mainly differ in the use of bioindicators. Macroinvertebrates are the most common biological indicator used to show disturbances in the water bodies. The aim of this paper is to explain how macroinvertebrates have been adopted to classify the ecological status of the water bodies by the Brazilian and EU water policies. In the WFD it was defined the AQEM biomonitoring program, which uses macroinvertebrates index. On the other hand, the PNRH does not require biomonitoring. The use of bioindicators is the main difference between both water management policies. It reflects the concept of the water as a resource in Brazil and as an ecosystem in the EU.
\end{abstract}

\section{KEYWORDS}

Water Policy, PNRH, WFD, Macroinvertebrates.

\section{INTRODUCTION}

Human activities impact most of the river basins and adjacent seas [1]. Worldwide water management has been improving in the recent past. Current biological characterization of the water bodies is an important parameter that is to be considered [2, 3, 4]. However, water management has traditionally looked at the physical-chemical measurements, which are enough to regulate effluent discharge and protect human health, but not to protect the ecosystems in a more detailed watershed management [5]. It means that the health of the aquatic ecosystems has been "virtually ignored in a management context" [6]. A water quality monitoring program is well structured when encompass physical, chemical and biological measurements [7].

The implementation of new water policies in Brazil and EU is a milestone to the development of these sites. Both sites have been undertaking frame works to tackle the water deterioration. Biological indicators are a requirement to whole water bodies from Europe through the Water Frame Directive (WFD). Locally some areas from Brazil are also adopting the same strategy. The use of macroinvertebrate communities in water management plans has been increasing 
[8]. Macroinvertebrates are the most common biological indicator used to show disturbances in the water bodies $[5,9]$. Their use can assist decision-makers in defining restoration and conservation strategies [10]. They also help to monitor biodiversity and water quality in watersheds [10].

The objective here is to spell out how macroinvertebrates have been adopted to classify the ecological status of the water bodies by the Brazilian and European Union water policies. Thus this paper will help us to understand how water management has used the benthic macroinvertebrates index, and what the legal differences are between the two sites.

\section{MAIN ENVIRONMENTAL IMPACTS IN WATERSHEDS}

The land use plays the most important role to the biochemical process in the watersheds and hence to its water features [11]. The growing level of the large-scale land-use enterprise infrastructure development, deforestation and agriculture have been the main factor steering environmental changes in most of the ecosystems [12], decreasing biodiversity [36].

Sediment load is the most critical by-product of the human activities which causes defilement of the natural environments. Sewage is forecasted to enhance with population growth due to the lack of treatment facilities. Chemical pollution from industries is also a huge impact to the water basins in the world [1].

Dams are the main factor affecting aquatic communities [1]. It threats the water basins due to changes in the water flow regime in the rivers which in turns influence the biodiversity in rivers [13]. Besides, it changes nutrient ratio to coastal zones [14].

Agriculture gives rise to huge environmental changes as well. It brings suspended solids due to erosion process [1]. Besides, agriculture nutrients pollute other aquatic habitats and groundwater, and its pesticides bioaccumulate in the food web [15]. Moreover agriculture is also the background of excessive water abstraction. Globally $70 \%$ of the water goes to irrigation $[1,16]$ and in countries where agriculture is the main activity it increases to $95 \%$ [16]. It leads to the abstraction of approximately $50 \%$ of the whole available surface water [12].

It is clear that human enterprises are linked with downstream habitat modification [1] and changes in the biological community. Human activities cause environmental deterioration, such as changes, the bioaccumulation of toxins, the presence/absence or abundance of indicator species or groups, and changes in community composition and ecosystem functioning [1].

\section{BIOMONITORING: THE USE OF BENTHIC MACROINVERTEBRATE}

Ecological integrity is a key concept for the management and protection of the ecosystems. [17]. Because it is difficult to monitor the whole ecosystem different shortcuts can be used [18]. One of them is the concept of bioindicators. This concept indicates the condition of an ecosystem and forms the basis of biological monitoring of environmental changes [19].

Macroinvertebrates have been one of the most promising bioindicators to carry out environmental assessment using aquatic biota [5, 9]. Aquatic benthic macroinvertebrates are used to assess the spatial and temporal changes in water quality [20]. According to Reice \& Wohlenberg [21] the advantages for using them are: duration of their life cycles which provides for long-term exposure to toxic substances in relation to other aquatic organisms, e.g. zooplankton; they live in contact with the sediment which increase their exposure to pollutants making it easier to detect levels of toxins in their body; given that decomposition takes place mainly in the bottom, studying benthic fauna is an effective tool to assess the ecosystem functioning. 
The background to biomonitoring was the Saprobic System developed by Kilkwitz and Marsson [22, 23]. This system is based on the pollution tolerances of indicator species form all components of the aquatic fauna, but mainly bacteria, algae, protozoans and rotifers [25]. From the Saprobic System, new biological monitoring programs were developed, such as: Biotic Condition Index [41], Biological Monitoring Working Party score system [42], Indice Biotico Esteso [43], Family Biotic Index [44], RIVPACS [45], AQEM [46], and so forth.

The results of these two last programs are influencing policy decisions about surface water management in Europe, where macroinvertebrate community assessments are being used as a tool for managing water uses, for ambient monitoring, and for evaluating the efficiency of pollution control measures $[25,26]$.

\section{CURRENT POLICIES}

\subsection{Legal bases for using Macroinvertebrates as indicators of water quality: EU Water Policy}

In 2000, the European Union (EU) adopted a new water policy, the Water Framework Directive (WFD). It established a legal framework to guarantee sufficient quantities of good quality water across EU. The WFD focus on inland and coastal surface waters and groundwater [26], aiming good ecological and chemical status for surface waters, good chemical and quantitative status for ground waters, and good ecological status for the surface waters by 2015 [27]. For surface waters, the objectives are to achieve 'good ecological status' and 'good chemical status', and for Heavily Modified Water Bodies/Artificial Water Bodies 'good ecological potential' and 'good surface water chemical status'. Further objectives are: "to make the water management on river basins, to combine emission limit values with environmental quality standards, to ensure that water prices provide adequate incentives for water users to use water resources efficiently, to involve citizens more closely, and to streamline legislation".

The WFD requires from member states a characterization and identification of water bodies along with an initial risk assessment considering not only the physical-chemical parameters but also the impact on aquatic ecosystems. This new approach is because the Water Framework Directive requires surface waters to meet 'good ecological and chemical status'. Thus any change (biological, physical or chemical) in the aquatic ecosystems must be taken into account [38]. The WFD prevent future environmental deterioration by the "nodeterioration principle', that does not allow expansions of environmental impacts due to upward in pollutant trends [38].

To achieve WFD goals, it is necessary to organize the information in a homogeneous method for comparison, analysis and evaluation of the environments. Therefore, the WFD demands for new and homogeneous methods of river assessments based on biological elements [28]. The AQEM biomonitoring program was especially developed to fulfill the WFD requirements $[26,29]$. It uses macroinvertebrates as biological indicators [30].

\subsection{Legal bases for using macroinvertebrates as indicators of water quality: brazilian Water Policy}

Currently, the most important law about water resource management is the so called Brazilian Water Law, no. 9433/1997 [31]. This law establishes that the water management must be done within the limits of the river basin and states that water plans are one of the instruments for bringing this law into reality. The public participation and the charging for the water usage were both included in this law. In January 2006, when it was approved the National Water 
Resources Plan (PNRH), Brazil was the first country in Latin America, and one of the first in the world to do so [32]. With this plan, Brazil met the UN deadline of creating an integrated national water management plan by the year 2005 .

Despite of all improvements done so far, the Brazilian legislation still does not require biomonitoring for determining water quality [31, 33]. In the Brazilian Water Law (no. 9433/1997) the aquatic communities were totally ignored [31]. This same author states that the water resources are not faced as aquatic ecosystems in that law. Usually the evaluation is performed only taking into account physical and chemical variables [34, 35].

In the very recent National Water Resources Plan, it is highlighted the concept that the water quality cannot be dissociated from the biotic aspect. However, the plan does not specify how to use bioindicators and does not obligate its usage. Locally, some states are already looking upon the ecological integrity to evaluate water quality, but is still incipient.

\section{DISCUSSION}

According to UNEP [1], the main failure in the water policy stems from: (i) reaching a general agreement among the stakeholders; (ii) implementing and enforcing this agreement (iii), and mapping the problems and their sources. Both Brazil and EU attempted to avoid these failures in their water policies, PNRH and WFD respectively.

To avoid the first failure both policies included and emphasized the participation of all stakeholders. In the case of the PNRH 12 Executive Commissions were created to incentive social mobilization and organize public state meetings which cooperated in the law's construction. In the WFD, the article 14 prescribes public participation by active involvement in all aspects of the implementation of the directive, consultation, and access to background information [39].

Regarding the second main failure, Brazil was one of the first countries in the world to implement an integrated water management plan. Additionally, Brazil has also created the National Water Resources Information System (SNIRH), which informs the water status of the Brazilian water basins to stakeholders. In Europe the WFD is requiring the member states to translate the WFD in National Laws by 2009 [26]. The Water Information System for Europe (WISE) is attempting to improve the link between citizens and scientific knowledge, providing information about the water quality in Europe.

To avoid the last main failure (mapping the problems and their sources), the Brazilian and European water policies have been undertaken different approaches. The classification and protection of water bodies in Brazil use physical chemical factors and are based on their usage [35]. There are considerations including environmental and biological assessment, however the biological factors are not compulsory. On the other hand, the WFD is built upon a new approach of 'ecological statuses for water bodies [40]. The AQEM biomonitoring program was created to fulfill the WFD by using macroinvertebrates as biological indicators.[30]. The principal aim of the WFD is to achieve 'good status' for all surface waters, which means both 'good ecological status' and 'good chemical status'. It can be hard, however, to harmonise the understanding of 'good ecological status' in all Member States, and to ensure that this common understanding is consistent with the definitions of the Directive. Macroinvertebrates will be of great importance in the intercalibration of 'good ecological status' among the EU member states (Sadin and Hering 2004).

The Brazilian and the European water laws have established parallel objectives as demonstrated in this paper. However, the Brazilian water law does not consider the water as an aquatic ecosystem [31], but as a public resource [34]. According to Karr and Chu [4] it is a failure not to see rivers as living systems and not to take biology seriously in management programs. Physical-chemical parameters are not enough to define an adequate protection to 
the aquatic ecosystem [2]. A water quality monitoring program is well structured when encompass physical, chemical and biological measurements [7]. The Brazilian policy does not require bioindicators (macroinvertebrates) for water assessment in spite of several researches about multimetric bioindicator index, e.g. Buss (2001), Egler (2002), Silveira et al. (2006) and [37].

In conclusion, the use of macroinvertabrates has been adopted to classify the ecological status of the water bodies by the use of the AQEM biomonitoring program in EU. In the Brazilian policy macroinvertebrates have not been required. The fact that the Brazilian water policy does not define the water as an aquatic ecosystem results in a lack of biomonitoring programs. This is the main difference between both water management policies.

\section{ACKNOWLEDGEMENTS}

We would like to thank Dr. Jan Herrmann, Dr. Márcia Marques and Dr. Daniel da Silva for scientific advice, and also Prof. Edna Granéli and Dr. Paulo Sérgio Salomon for the academic incentive. We are also grateful to the Department of Environmental Engineering, University of Kalmar, for providing convenient working facilities.

\section{REFERENCE}

[1] UNEP, 2006. Challenges to International Waters - Regional Assessments in a Global Perspective. United Nations Environmental Programme, Nairobi, Kenya.

[2] Adler, R. W., 1995. Filling the gaps in water quality standards: legal perspectives on biocriteria. In: W. S. DA VIS and T.P.SIMON. Biological Assessment and Criteria. Boca Raton: Lewis Publishers, 345-358.

[3] Davis, W. and Simon, T., 1995. Biological Assessment and Criteria: Tool for water resource planning and decision making. Edt Lewis Publishers. ISBN: 0-87371-894-1.

[4] Karr, J. R. and Chu, E.W, 1999. Restoring Life in the Running Waters: Better Biological Monitoring. Edt Lewis Publishers. Edt Island Press. ISBN 1-55963-674-2.

[5] Norris, R. H. \& Thoms, M. C., 1999. What is river health? Freshwater Bio. Vol 41. 197-209.

[6] LeRoy, N.; Allan J. D., Bain, M. B., Karr, J. R., Prestegaard, K. L., Richter, B. D., Sparks, R. E., and Stromberg, J. C.;1997.The Natural Flow Regime - A paradigm for river conservation and restoration.

[7] Hynes, H.B.N., 1960. The Biology of polluted Waters. University of Toronto Press. ISBN: 0802016901

[8] Karr, J.R., L. S. Fore \& E. W. Chu, 1997. Making biological monitoring more effective: integrating biological sampling with analysis and interpretation. Technical Report. USA/EPA: 160 .

[9] Rosenberg, D. M. \& V. H. Resh, 1992. Introduction to freshwater biomonitoring and benthic macroinvertebrate. In Rosenberg, D. M. \& V. H. Resh (eds), Freshwater Biomonitoring and Benthic Macroinvertebrate. Chapman \& Wall Inc, London: 488 pp.

[10] Marques, M. M.; Barbosa, F.; 2001. Biological quality of waters from an impacted tropical watershed (middle Rio Doce basin, southeast Brazil), using benthic macroinvertebrate communities as an indicator. Hydrobiologia. Vol 457. 69-76.

[11] Allan, J. D., D. L. Erickson, and J. Fay. 1997. The influence of catchment land use on stream integrity across multiple spatial scales. Freshwater Biology. Vol 37.149-161.

[12] Vitousek, P.M., Mooney,H.A., Lubchenco, J., and Melillo, J.M.; 1997. Human Domination of Earth's Ecosystems. Science. Vol. 277. n 5325. 494 - 499. 
[13] Bunn, S. E. \& Arthington; A. H., 2002. Basic Principles and Ecological Consequences of Altered Flow Regimes for Aquatic Biodiversity. Envir. Manag. Vol 30. n 4. 492-507.

[14] Humborg, C., Ittekkot, V., Cociasu, A., and Bodungen, B.V.; 1997. Effect of Danube River dam on Black Sea biogeochemistry and ecosystem structure. Nature. Vol 386. 385-388

[15] Tilman, D., Cassman, K. G., Matson, P. A., Naylor, R. and Polasky, S., 2002. Agricultural sustainability and intensive production practices. Nature. Vol 418. 671677.

[16] Vandeweerd, V.; Unpublished. Water Frame Directive (2007).

[17] Andreasen, J. K., O'neill, R. V., Noss, R., and Slosser, N. C., 2001. Considerations for the development of a terrestrial index of ecological integrity. Ecological Indicators. Vol 1. 21-35.

[18] Simberloff, D., 1998. Flagships, umbrellas, and keystones: Is singles-species management passé in the landscape era? Biol. Conserv. Vol 33. 247-257.

[19] Zacharias, M. A. and Roff, J.C., 2001. Use of focal species in marine conservation and management: a review and critique. Aquat. Conserv.: Mar. Freshwat. Ecosyst. Vol 11. n. 1. 59-76.

[20] Lenat, D. R.; 1988. Water quality assessment of streams using a qualitative collection method for benthic macroinvertebrates. J. N. Am. Benthol. Soc. Vol. 7. n 3. 222-233

[21] Reice, S. R. And Wohlenberg, M., 1993. Monitoring freshwater benthic macroinvertebrates and benthic processes: measures for assessment of ecosystem health. In: Freshwater biomonitoring and benthic macroinvertebrates. Chapman \& Hall, Inc.

[22] R Kolkwitz, M Marsson, 1909. Principles for the bioassessment of waterbodies according to their flora and fauna. Mitt. Der Klg. Pruf. fur Wass. Abw. Berlin-Dahlem,

[23] N Pauw, G Vanhooren, 1983. Method for biological quality assessment of watercourses in Belgium. Hydrobiologia. Vol 100. n 1. 153-168.

[24] Likens, G.E., Bormann, F.H., Johnson, N.M., Fisher, D.W. and Pierce, R.S.; 1970. The effect of forest cutting and herbicide treatment on nutrient budgets in the Hubbard Brook watershed-ecosystem. Ecol Monogr. Vol 40. 23-47.

[25] Metcalfe, JL, 1989. Biological Water Quality Assessment of Running Waters Based on Macroinvertebrate Communities: History and Present Status in Europe. Environmental Pollution ENPOEK. Vol 60. n 1-2. 101-139.

[26] Commission of the European Communities Brussels, 2007 , Communication from the Commission to the European Parliament and the Council towards sustainable water management in the European Union- First stage in the implementation of the Water Framework Directive 2000/60/EC -[SEC(2007) 362][SEC(2007) 363].

[27] Department for Environment, Food and Rural Affairs,Department of the Environment Northern Ireland,Scottish Executive, Welsh Assembly Government,March 2005, Water Framework Directive (WFD): Note from the UK administrations on the next steps of Characterization.

[28] Rolauffs P., Ilse Stubauer I., Zahr S., Brabec K., Moog O., 2004. Integration of the saprobic system into the European Union Water Framework Directive Case studies in Austria, Germany and Czech Republic. Hydrobiologia. Vol 516. 285-298.

[29] Logan P., Furse M., 2002. Preparing for the European Water Framework Directive making the links between habitat and aquatic biota, Aquatic Conserv: Mar. Freshw. Ecosyst. Vol 12. 425-437.

[30] Logan P., 2001, Ecological quality assessment of rivers and integrated catchment management in England and Wales. InScientific and Legal Aspects of Biological Monitoring in Freshwater, Ravera O (ed). Journal of Limnology. Vol 60. 25-32. 
[31] Togoro, E. S., 2006. Qualidade da água e integridade biótica: estudo de caso num trecho fluminense do rio paraiba do sul. Trabalho Final de Mestrado em Engenharia Ambiental. Universidade do Estado do Rio de Janeiro.

[32] WWF, 2006. "Brazil approves national water plan". <http://www.panda.org/news>

[33] Buss, D. F., Baptista, D. F., Nessimian, J. L., 2003. Bases conceituais para a aplicação de biomonitoramento em programas de avaliação da qualidade da água de rios. Cad. Saúde Pública. Vol 19. n.2. 465-473.

[34] BRASIL. Lei das Águas. Lei 9.433, de 8 de janeiro de 1997. Institui a Política Nacional de Recursos Hidricos, cria o Sistema Nacional de Gerenciamento de Recursos Hídricos, regulamenta o inciso XIX do art. 21 da Constituição Federal, e altera o art. $1^{\circ}$ da Lei 8.001, de 13 de março de 1990, que modificou a Lei 7.990, de 28 de dezembro de 1989

[35] BRASIL. Resolução CONAMA N³ 357. RESOLUÇÃO CONAMA N 357, de 17 de março de 2005. Dispõe sobre a classificação dos corpos de água e diretrizes ambientais para o seu enquadramento, bem como estabelece as condições e padrões de lançamento de efluentes, e dá outras providências.

[36] Chapin, F.S., Zavaleta, E.S., Eviner V.T., Naylor, R.L., Vitousek, P. M., Reynolds, H. L., Hooper, D. U., Lavorel, S., Sala,O.E., Hobbie, S.E., Mack, M.C. and Diaz, S., 2000. Consequences of changing biodiversity. Nature. Vol 405. 234-242

[37] Baptista, D. F., Buss, D. F., Egler, M., Giovanelli, A., Silveira, M. P., Nessimian, J. L., 2007. A multimetric index based on benthic macroinvertebrates for evaluation of Atlantic Forest streams at Rio de Janeiro State, Brazil. Hydrobiologia. Vol 575. 83-94.

[38] DEFRA (Department for Environmental, Food and Rural Affairs), DENI (Department of the Environment Northern Ireland, SE (Scottish Executive), WAG ( Welsh Assembly Goverment, 2005. Water Framework Directive (WFD): Note from the UK administrations on the next steps of Characterisation.

[39] Brugge, R. and Rotmans, J., 2007. Towards transition management of European water resources. Water Resour Manage. Vol 21. 249-267.

[40] Steyaert, P., and Ollivier, G., 2007. The European Water Framework Directive: how ecological assumptions frame technical and social change. Ecology and Society. Vol 12. n1. 25.

[41] Winget, R. N., F. A. Mangun, 1979. Biotic Condition Index: Integrated Biological, Physical and Chemical Stream Parameters for Management. US Forest Service, Intermountain region, Provo, Utah.

[42] Armitage, P. D., D. Moss, J. F. Wright \& M. T. Furse, 1983. The performance of a new biological water quality score system based on macroinvertebrates over a wide range of unpolluted running-water sites. Water Research. Vol 17. 333-347.

[43] Ghetti, P. F., 1997. Indice Biotico Esteso (I.B.E). I Macroinvertebrati nel Controllo della Qualita' degli Ambienti di Acque Correnti. Provincia Autonoma di Trento. 222 pp.

[44] Hilsenhoff, W. L., 1988. Rapid field assessment of organic pollution with a family-level biotic index. Journal of the North American Benthological Society. Vol 7. n 1. 65-68.

[45] Clarke R. T., J. F. Wright \& M. T. Furse, 2003. RIVPACS models for predicting the expected macroinvertebrate fauna and assessing the ecological quality of rivers. Ecological Modelling. Vol 160. 219-233.

[46] Hering, D., O. Moog, L. Sandin \& P. F. M. Verdonschot, 2004. Overview and application of the AQEM assessment system. Hydrobiologia. Vol 516. 1-20. 